\title{
Penyuluhan Hukum Tentang Kekerasan Dalam Rumah Tangga (KDRT) Kepada Anggota Polisi Dan Penyidik Di Kepolisian Resort (POLRES) Kabupaten Tanjung Jabung Barat
}

\author{
Elly Sudarti, Syofyan Nur, Khabib Nawawi, Nys. Arfah, Erwin \\ Fakultas Hukum Universitas Jambi
}

\begin{abstract}
Abstrak: Pengadian Pada Masyarakat bertujuan: (1) Untuk memberikan pemahaman tentang Undang-Undang Nomor 23 Tahun 2004 Tentang Kekerasan Dalam Rumah Tangga; (2) Untuk memberikan pemahaman bentuk perlindungan hukum terhadap korban kekerasan dalam rumah tangga yang harus diberikan oleh pihak Kepolisian; (3) Untuk memberikan pemahaman kepada Penyidik tentang mediasi penal dalam tindak pidana kekerasan dalam rumah tangga. Kegiatan pengabdian pada masyarakat ini dilatarbelakangi oleh fenomena yang terjadi di dalam masyarakat. . Masalah KDRT itu sendiri sebetulnya masalah yang sering terjadi dalam kehidupan berumah tangga, tetapi sebagaian masyarakat tidak menganggap yang dialaminya sebagai suatu perbuatan yang salah dimata hukum. Oleh sebab itu masyarakat perlu diberikan pemahaman tentang KDRT, sehingga jika terjadi atau mengalami KDRT, korban dapat mengambil langkah-langkah secara hukum. Metode yang digunakan adalah metode partisipatif diharapkan mitra dapat berperan aktif dalam kegiatan penyuluhan hukum dalam bentuk (1) Ceramah Sosialisasi UU Nomor 23 Tahun 2004 Tentang KDRT; (2) Penyuluhan hukum tentang materi UU Nomor 23 Tahun 2004 Tentang KDRT; (3) Penyelesaian KDRT melalui mediasi penal. Kesimpulan: Penyuluhan Hukum Tentang Kekerasan Dalam Rumah Tangga (KDRT) Kepada Anggota Polisi Dan Penyidik di Kepolisian Resort (POLRES) Kabupaten Tanjung Jabung Barat", menunjukkan bahwa akseptabilitas yakni tingkat penyerapan mitra terhadap kegiatan mengalami peningkatan pengetahuan dan pemahaman mitra tentang materi kegiatan. Yaitu adanya peningkatan pengetahuan dan pemahaman peserta tentang materi Undang-Undang Nomor 23 Tahun 2004 Tahun Tentang Penghapusan Kekerasan Dalam Rumah Tangga, mitra mampu menyampaikan ide atau pemikiran berkaitan dengan KDRT serta dalam penyelesaian KDRT mitra telah menerapkan mediasi penal. Saran: Kegiatan penyuluhan sangat bermanfaat bagi masyarakat, khususnya Aparat Penegak Hukum (Kepolisian) dalam penanggulangan KDRT, karena penegakan hukum tidak harus diselesaikan dengan penegakan hukum pidana, contohnya dalam KDRT dapat dilakukan upaya mediasi penal.
\end{abstract}

Kata Kunci: Pelaku, Korban, KDRT, Mediasi Penal

\section{PENDAHULUAN}

\subsection{Analisis Situasi}

Tujuan perkawinan adalah untuk membentuk keluarga atau rumah tangga yang bahagia dan kekal berdasarkan Ketuhanan Yang Maha Esa. Rumah tangga adalah organisasi terkecil dalam kehidupan masyarakat yang terdiri dari seorang pria dan wanita sebagai suami isteri dan anak-anaknya. Interaksi antara suami dan anak-anaknya dalam kehidupanrumah tangga yang didasarkan pada Ketuhanan Yang Maha Esa, seharusnya mampu menciptakan kehidupan berumah-tangga yang bahagia. Kenyataannya masih banyak terjadi kekerasan dalam kehidupan berumah-tangga. Padahal setiap insan manusia dalam rumah tangga berhak mendapatkan rasa aman dan bebas dari segala bentuk kekerasan.

Kekerasan dalam rumah tangga dapat terjadi pada istri dan anak-anak serta mereka yang berada dalam lingkup rumah tangga merupakan masalah yang sulit diatasi. Masyarakat pada umumnya menganggap bahwa anggota keluarga itu merupakan milik laki-laki dan masalah kekerasan dalam rumah tangga adalah masalah pribadi yang tidak dapat dicampuri 
oleh orang lain. Sementara itu, sistem hukum dan sosial budaya yang ada bukan menjamin perlindungan terhadap perempuan korban kekerasan dalam rumah tangga.

Perempuan yang menjadi korban kekerasan dalam rumah tangga sebenarnya mempunyai hak atas rasa aman dan perlindungan dari ancaman, bebas dari penyiksaan atau perlakuan yang merendahkan derajat martabat manusia berdasarkan azas-azas penghormatan terhadap perempuan, keadilan dan kesetaraan jender serta arti diskriminasi, sebagaimana diatur Undang-Undang Nomor 29 Tahun 1999 tentang Hak Asasi Manusia.

Segala bentuk kekerasan terhadap perempuan merupakan pelanggaran HAM dan kejahatan terhadap eksistensi kemanusiaan serta merupakan bentuk diskriminasi yang harus dihapus karena tidak sesuai dengan deklarasi PBB tentang HAM dan Konvensi Internasional tentang penghapusan segala bentuk diskriminasi terhadap perempuan.

Data statistic yang lengkap mengenai kasus kekerasan dalam rumah tangga (KDRT) yang terjadi di seluruh Indonesia memang tidak tersedia, Sedikitnya ada 2 (dua) alasan yang saling berkaitan untuk menjawab mengenai kekosongan data tersebut yakni: Pertama, KDRT sejauh ini tidak dikenal sebagai kejahatan dalam masyarakat meskipun terjadi di banyak tempat dalam bentuk seperti perkosaan, penyiksaan terhadap isteri, anak, incest, pemasungan, pembunuhan dan bentuk kekerasan lainnya. Dalam kasus-kasus tertentu, korban yang berupaya melindungi diri dan membalas perlakuan pelaku dengan mencederainya, akhirnya malah dituntut dan dianggap melakukan kejahatan lainnya seperti pembunuhan. Persepsi yang berkembang di masyarakat selama ini menganggap masalah kekerasan dalam rumah tangga (KDRT) sebagai urusan pribadi (personal) dan karenanya pihak-pihak lain (pihak luar termasuk aparat penegak hukum atau polisi), tidak sepatutnya ikut campur di dalamnya (intervensi).

Kedua, kebanyakan korban tidak bisa berbicara secara terbuka mengenai kasus yang dialaminya dalam keluarga. Ini bisa dimengerti karena kasus-kasus tersebut tidak dianggap atau diremehkan oleh masyarakat di sekitarnya. Para tetangga atau saksi lainnya biasanya tidak serta merta membantu korban. Korbanlah yang banyak menanggung kerugian seperti biaya pengobatan untuk pemulihan, mencari perlindungan diri atau menanggung aib. Namun demikian, sejumlah informasi dan studi yang tersedia sudah cukup untuk menunjukkan fakta, bahwa perempuan menjadi korban kekerasan karena adanya ketidakseimbangan relasi antara laki-laki dan perempuan. Ini terjadi dalam relasi pasangan perkawinan, keluarga / pasangan intim (Jurnal Prempuan, 2002: 9).

Rumah tangga semestinya adalah tempat berlindung bagi seluruh anggota kaluarga, namun pada kenyataannya justru banyak rumah tangga menjadi tempat penderitaan dan penyiksaan. Undang-Undang Nomor 23 Tahun 2004 Tentang Penghapusan Kekerasan Dalam Rumah Tangga,

Pasal 1: Kekerasan dalam rumah tangga adalah, "setiap perbuatan terhadap seseorang terutama perempuan yang berakibat timbulnya kesengsaraan atau penderitaan secara fisik, seksual, psikologis, dan/atau penelantaran rumah tangga termasuk ancaman untuk melakukan perbuatan pemaksaan, atau perampasan kemerdekaan secara melawan hokum dalam lingkup rumah tangga"

Lingkup rumah tangga menurut Pasal 2 Undang-Undang Nomor 23 Tahun 2004, meliputi: 
a. Suami, isteri dan anak;

b. Orang-orang yang mempunyai hubungan keluarga dengan orang sebagaimana dimaksud pada huruf a, karena hubungan darah, perkawinan, persusuan, pengasuhan dan perwalian yang menetap dalam rumah tangga tersebut;

c. Orang yang bekerja membantu rumah tangga dan menetap dalam rumah tangga tersebut.

Korban menurut Pasal 1 ayat (3) Undang-Undang Nomor 23 Tahun 2004, adalah orang yang mengalami kekerasan dan/atau ancaman kekerasan dalam lingkup rumah tangga.

Seharusnya antara suami, isteri dan anak-anak saling hormat menghormati dan hidup rukun sebagaimana Pasal 33 Undang-Undang Nomor 1 Tahun 1974 tentang Perkawinan, bahwa: "Antara suami mempunyai kewajiban untuk saling cinta mencintai, hormat menghormati, setia dan member bantuan lahir batin yang satu kepada yang lain."

Adanya ketentuan tersebut masing-masing pihak, suami dan isteri akan dapat menghindari perselisihan atau tindakan fisik yang cenderung menyakiti dan membahayakan jiwa seseorang. Kenyataan berbicara lain sebagaimana dilaporkan Rifka Annisa Wome's centre, bahwa:

"Sejak tahun 1994 sampai tahun 2003, kekerasan dalam rumah tangga mencapai 1511 kasus yang hampir setiap tahun mengalami peningkatan. Sejak tahun 1994 ada 18 Kasus, tahun 1995 ada 82 kasus, 1996 sebanyak 134 kasus, kemudian pada tahun 1997 menjadi 188 kasus. Selanjutnya tahun 1998 ada 208 kasus dan 1999 ada 182 kasus. Dari 706 kasus pengaduan terbanyak mencapai $70 \%$ adalah korban kekerasan suami. Bahkan ada yang menyebabkan kebutaan, tetapi ironisnya hanya $2 \%$ saja yang bersedia membawa kasusnya, baik ke pengadilan maupun melapor ke Kepolisian." (Rika Saraswati, 2006: 2)

Banyaknya kasus yang tidak dilaporkan ke kepolisian atau sampai ke meja hijau karena masih adanya pandangan patriaki (Rika Saraswati, 2006:2), memandang urusan rumah tangga adalah urusan pribadi yang tidak boleh dicampuri oleh orang lain. Dari sisi hukum tentunya pandangan demikian tidak lagi dapat dipertahankan, karena perempuan dan urusan kekerasan termasuk tindak pidana yang akibat hukumnya diatur secara hukum dan setiap orang berhak memperoleh perlindungan secara hukum. Selain itu, kekerasan dalam rumah tangga sebenarnya juga merupakan kejahatan terhadap individu dan masyarakat yang pelakunya seharusnya dapat dipidana, tetapi sulit ditangani karena dianggap sebagai urusan internal rumah tangga orang. Masyarakat seharusnya tidak berpikir sempit, artinya jika masyarakat masih berpikir bahwa masalah kekerasan dalam rumah tanggah adalah urusan internal rumah tangga, maka selama itu pula kasus kekerasan dalam rumah tangga tidak dapat ditangani secara hukum.

Dalam Pasal 89 KUHP dijelaskan bahwa: "membuat orang pingsan atau tidak berdaya disamakan dengan kekerasan." Apabila KUHP sudah mengatur tindak pidana yang dapat disetarakan dengan kekerasan, bahkan dapat dikenakan perbuatan tersebut dalam KUHP dapat dikatagorikan perbuatan "penganiayaan" yang diancam dengan Hukum sebagaimana Pasal 354 KUHP. Persoalannya adalah mengapa masih diperlukan UU No 23 Tahun 2004 Tentang Kekerasan Dalam Rumah Tangga . Posisi pria sebagai suami seharusnya menciptakan 
kenyamanan, memberi perlindungan kepada isterinya dan memberi nafkah, tetapi malah sebaliknya menciptakan kekerasan. Mengingat peranan dan fungsinya, maka KUHP tidak cukup untuk dikenakan kepada pelaku.

Selain itu, ada perbedaan antara pria dan wanita baik secara biologis maupun psikisanatomis dan fisiologis sehingga antara pria dan wanita seharusnya saling melengkapi bukannya sebaliknya menyakiti. Perbedaan itu membawa dampak social yang cukup tinggi, sehingga ketentuan-ketentuan huku dalam KUHP khususnya pasal-pasal tentang kejahatan terhadap tubuh dan nyawa sebagaimana diatur dalam Pasal 90, 351, 352, 353, 354 tidak cukup memadai (Herkutanto, 2007: 265).

Berbagai masalah berkaitan dengan perlindungan hukum terhadap korban tindak pidana kekerasan dalam rumah tangga yang ketentuannya diatur dalam pasal-pasal KUHP tentang penganiayaan, derajat luka yang menentukan sanksi pidana atas penganiayaan ringan, sedang, dan berat masih belum terinci secara tegas. Untuk mengukur derajat luka ketentuan yang ada menggunakan indicator "timbulnya penyakit" dan "halangan menjalankan pekerjaan."

Sejak diberlakukannya Undang-Undang Nomor 23 Tahun 2004 oleh pemerintah, telah merubah cara pandang, semula kekerasan dalam rumah tangga sebagai urusan pribadi kini telah menjadi urusan dan kepentingan publik. Kepedulian pemerintah terhadap kasus ini terbukti dengan berlakunya Undang-Undang Nomor 23 Tahun 2004 Tentang Penghapusan Kekerasan Dalam Rumah Tangga.

Adanya kedua perangkat hukum di atas tidak serta merta menyadarkan perempuan dan masyarakat yang menjadi korban kekerasan untuk menyelesaikan persoalan kekerasan dalam rumah tangga sebagai tindak pidana yang dapat dihukum melalui hukum pidana, tetapi lebih memilih dengan menempuh secara perdata melalui perceraian. Seharusnya kekerasan dalam tangga adalah tindak pidana yang melanggar kepentingan public yang dapat diselesaikan dengan penegakan hukum pidana. Sedikitnya kasus yang diselesaikan secara pidana menunjukkan bahwa ada keengganan dari korban untuk menempuh penyelesaian kasusnya secara pidana.

Menurut Kepala Badan Pemberdayaan Perempuan (BPMPP) Propinsi Jambi Eny Harriyati, kasus kekerasan terhadap perempuan mengalami peningkatan yang signifikan, tahun 2012 ditemukan sebanyak 50 kasus KDRT, sedangkan tahun 2013 ada 56 kasuss. Pada tahun 2014, hingga bulan Februari terdapat 16 kasus. Menurut ibu Eny kasus kekerasan dalam rumah tangga (KDRT) mengalami peningkatan di tahun 2014 (Harian Jambi, 19 Februari 2014).

Jika dilihat permasalahan di atas, maka perlindungan terhadap korban kekerasan dalam rumah tangga sebagaimana diamanatkan oleh Undang-Undang Nomor 23 Tahun 2004 belum terlaksana. Sehubungan dengan masalah perlindungan terhadap korban kekerasan dalam rumah tangga di Kepolisian Resort Tanjung Jabung Timur, khususnya anggota kepolisian dan penyidik setempat belum pernah mendapatkan penyuluhan tentang kekerasan dalam Rumah Tangga (KDRT). Masalah KDRT itu sendiri sebetulnya masalah yang sering terjadi dalam kehidupan berumah tangga, tetapi sebagian masyarakat tidak menganggap yang dialaminya sebagai suatu perbuatan yang salah dimata hukum. Oleh sebab itu masyarakat 
perlu diberikan pemahaman tentang KDRT, sehingga jika terjadi atau mengalami KDRT, korban dapat mengambil langkah-langkah secara hukum.

Persoalan perlindungan hukum terhadap korban kekerasan dalam rumah tangga, merupakan masalah yang cukup kompleks, karena masyarakat masih menganggap masalah kekerasan dalam rumah tangga adalah masalah domestic dalam rumah tangga, padahal kekerasan dalam rumah tangga terrmasuk masalah kejahatan. Adapun tema penyuluhan hukum mengangkat permasalahan sebagai berikut: "Masih banyaknya perbuatan-perbuatan kekerasan yang dilakukan oleh suami terhadap isteri dalam rumah tangga, terhadap isteri sebagai korban tidak mendapatkan perlindungan, sementara terhadap pelaku tidak diproses secara hukum. Penyuluhan hukum untuk memberikan pemahaman kepada masyarakat, khususnya korban KDRT Tentang Undang-Undang Nomor 23 Tahun 2004 merupakan hal yang sangat penting untuk dilakukan.

Oleh sebab itu penyuluhan hukum tentang Kekerasan Dalam Rumah Tangga (KDRT) Terhadap Anggota Kepolisian dan Penyidik di Kepolisian Resort Kabupaten Tanjung Jabung Barat dirasa penting untuk dilaksanakan, mengingat korban kekerasan dalam rumah tangga dapat terjadi kepada siapa saja dalam lingkup rumah tangga. Terhadap korban kekerasan dalam rumah tangga harus mendapatkan perlindungan.

\subsection{Permasalahan Mitra}

Persoalan perlindungan hukum terhadap korban kekerasan dalam rumah tangga, merupakan masalah yang cukup kompleks, karena masyarakat masih menganggap masalah kekerasan dalam rumah tangga adalah masalah domestic dalam rumah tangga, padahal kekerasan dalam rumah tangga terrmasuk masalah kejahatan. Permasalahan dapat diidentifikasi sebagai berikut:

1. Mitra mengetahui tetapi belum memahami isi Undang-Undang Nomor 23 Tahun 2004 Tentang Penghapusan Dalam Rumah Tangga.

2. Mitra belum memahami bentuk kekerasan psikis dan penelantaran dalam rumah tangga yang sering terjadi dalam masalah rumah tangga.

3. Mitra belum memahami bentuk perlindungan hukum terhadap korban kekerasan dalam rumah tangga yang harus diberikan oleh pihak Kepolisian.

4. Mitra belum memahami mediasi penal dalam tindak pidana kekerasan dalam rumah tangga.

5. Mitra belum memahami perbedaan kodrat dan gender dalam kaitannya dengan kekerasan dalam rumah tangga.

\subsection{Tujuan Pengadian Pada Masyarakat}

1. Untuk memberikan pemahaman tentang Undang-Undang Nomor 23 Tahun 2004 Tentang Kekerasan Dalam Rumah Tangga;

2. Untuk memberikan pemahaman bentuk kekerasan psikis dan penelantaran dalam rumah tangga yang sering terjadi dalam masalah rumah tangga;

3. Untuk memberikan pemahaman bentuk perlindungan hukum terhadap korban kekerasan dalam rumah tangga yang harus diberikan oleh pihak Kepolisian; 
4. Untuk memberikan pemahaman kepada Penyidik tentang mediasi penal dalam tindak pidana kekerasan dalam rumah tangga;

5. Untuk memberikan pemahaman kepada Penyidik perbedaan kodrat dan gender dalam kaitannya dengan kekerasan dalam rumah tangga.

\subsection{Manfaat Pengabdian Pada Masyarakat}

1. Diharapkan mitra memperoleh pengetahuan yang tepat, memahami isi aturan mengenai kekerasan dalam rumah tangga sebagaimana diatur dalam Undang-Undang Nomor 23 Tahun 2004 tentang Penghapusan Kekerasan Dalam Rumah Tangga.

2. Diharapkan setelah mengikuti kegiatan penyuluhan hukum ini, mitra mengetahui, memahami hak-hak maupun langkah-langkah yang harus dilakukan Korban Kekerasan Dalam Rumah Tangga.

3. Setelah mitra mengikuti kegiatan pengabdian pada masyarakat diharapkan ada peningkatan pemahaman yang mendalam terhadap isi Undang-Undang Nomor 23 Tahun 2004 Tentang Kekerasan dalam Rumah Tangga, sehingga diharapkan terhadap mitra ada perubahan sikap atau perilaku tidak melakukan maupun mengalami kekerasan dalam rumah tangga.

\section{TARGET DAN LUARAN}

\subsection{Target}

Kegiatan pengabdian pada masyarakat Penyuluhan Hukum Tentang Kekerasan Dalam Rumah Tangga (KDRT) Kepada Anggota Polisi Dan Penyidik Di Kepolisian Resort (POLRES) Kabupaten Tanjung Jabung Barat. Sebenarnya siapa saja mempunyai potensi untuk menjadi baik sebagai pelaku maupun sebagai korban KDRT dalam lingkup rumah tangga. Pada umumnya yang rentan mengalami kekerasan dalam rumah tangga adalah perempuan dan anak. Target dan sasaran penyuluhan hukum ini ditujukan kepada: Anggota Polisi Dan Penyidik Di Kepolisian Resort (POLRES) Kabupaten Tanjung Jabung Barat. Dengan adanya penyuluhan hukum tentang KDRT dan Perlindungan Hukum Bagi Korban KDRT, diharapkan ada peningkatan pemahaman tentang KDRT, dalam proses penyelesaian pada kondisi tertentu tidak selalu mengedepankan kepastian hukum tetapi penyidik dapat menerapkan mediasi penal.

\subsection{Luaran}

1. Mitra mampu menyerap pengetahuan tentang kekerasan dalam rumah tangga KDRT yang diatur dalam Undang-Undang No 23 Tahun 2004 Tentang Kekerasan Dalam Rumah Tangga.

2. Mitra mampu memahami isi Undang-Undang Nomor 23 Tahun 2004 kekerasan dalam Rumah Tangga.

3. Laporan pelaksanaan kegiatan dan jurnal pengabdian pada masyarakat.

\section{METODE PELAKSANAAN}

Adapun metode yang dilakukan dalam kegiatan pengabdian masyarakat ini adalah dalam bentuk penyuluhan hukum yang dilakukan dengan beberapa tahapan sebagai berikut:

1. Persiapan

2. Materi kegiatan 
3. Kegiatan Pokok

4. Evaluasi

5. Penyusunan Laporan

\subsection{Persiapan,}

Merupakan kegiatan awal yang dilakukan dengan cara Audiensi kepada Aparat Kepolisian Resort Kabupaten Tanjung Jabung Barat Bapak Kasat Reskrim AKP. Pandit Wasianto, S.H., S.I.K., NRP 83091418, guna meminta kesediaan untuk menjadi Mitra, POLRES Tanjung Jabung Barat berada di Kecamatan Tungkal Ilir. Selanjutnya Tim penyuluhan menyampaikan surat permohonan serta izin untuk mengadakan penyuluhan Lokasi sasaran. Persiapan untuk menentukan lokasi kegiatan, jumlah peserta, hari dan tanggal kegiatan. Tahap berikutnya menyebarkan undangan dan konfirmasi kehadiran peserta dalam kegiatan pengabdian pada masyarakat.

\subsection{Materi kegiatan,}

Materi yang akan disampaikan adalah tentang Kekerasan Dalam Rumah Tangga (KDRT) OLEH NARASUMBER. Kegiatan ini dihadiri oleh kurang lebih 50 orang, terdiri atas Anggota Kepolisian dan Penyidik di Kepolisian Resort Tanjung Jabung Barat, Kecamatan Tungkal Ilir Kabupaten Tanjung Jabung Barat dengan materi sebagaimana diatur dalam Undang-Undang Nomor 23 Tahun 2004 Tentang Penghapusan Kekerasan Dalam Rumah Tangga, sebagai berikut:

1. Pengertian kekerasan Dalam Rumah tangga

2. Larangan kekerasan Dalam rumah Tangga

3. Perlindungan Terhadap korban.

4. Pemulihan Korban.

\subsection{Kegiatan Pokok}

1. Penyampaian materi dengan metode ceramah dengan materi tentang KDRT dan perlindungan terhadap korban kekerasan dalam rumah tangga. (KDRT).

2. Penyampaian materi dengan memberikan contoh-contoh kasus berkaitan dengan kekerasan yang dialami korban KDRT yang sering terjadi di masyarakat.

3. Diskusi dan tanya jawab antara penyaji materi dengan peserta penyuluhan hokum

\subsection{Evaluasi}

Evaluasi atas pelaksanaan kegiatan dilakukan baik terhadap proses maupun hasil yang didasarkan pada beberapa aspek, sebagai berikut:

- Kehadiran peserta

- Keaktifan peserta

- Relevansi

- Akseptabilitas

- Ketepatgunaan

- Dampak jangka panjang 


\subsection{Penyusunan Laporan}

Penyusunan laporan merupakan salah satu bentuk pertanggungjawaban tim atas kegiatan pengabdian masyarakat yang telah dilakukan terhadap seluruh kegiatan mulai dari persiapan, pelaksanaan sampai evaluasi dengan berpedoman pada ketentuan yang berlaku.

\section{KELAYAKAN UNIVERSITAS JAMBI}

Perguruan Tinggi dalam hal ini diwakili oleh Lembaga Pengabdian Masyarakat (LPM) bertindak sebagai penanggung jawab seluruh kegiatan pengabdian yang dilakukan oleh Dosen di lingkungan Universitas Jambi dalam pelaksanaan TRI DHARMA Perguruan Tinggi. Alokasi dana yang tersedia sangat menunjang kegiatan pengabdian dan ketersediaan tenaga ahli di bidangnya masing-masing.

Universirtas Jambi selaku lembaga pendidikan yang mengemban tugas pelaksana Tri DHARMA PERGURUAN TINGGI bertanggung jawab atas atas pelaksanaan program tersebut, baik penyiapan tenaga ahli maupun fasilitas, sarana prasarana serta alokasi dana yang tersedia sangat menunjang kegiatan pengabdian dan ketersediaan tenaga ahli di bidangnya masing-masing.

Lembaga Pengabdian Pada Masyarakat (LPM), merupakan salah satu perangkat lembaga struktural yang ada di Universitas Jambi, secara teknik operasional merupakan Lembaga yang bertanggung jawab dalam pelaksanaan kegiatan pengabdian pada masyarakat.

Kami salah satu Tim pengusul dari unsur akademisi Fakultas Hukum Universitas Jambi, akan melakukan kegiatan pengabdian pada masyarakat dengan judul; "Penyuluhan Hukum Tentang Kekerasan Dalam Rumah Tangga (KDRT) Kepada Anggota Polisi Dan Penyidik Di Kepolisian Resort (POLRES) Kabupaten Tanjung Jabung Barat”.

\section{HASIL DAN PEMBAHASAN}

\subsection{Pelaksanaan Penyuluhan}

\section{a. Lokasi Penyuluhan}

Kegiatan penyuluhan dilaksanakan di Kantor Aula Kepolisian Resort (POLRES) Kabupaten Tanjung Jabung Barat.

\section{b. Materi dan Jadwal Penyuluhan}

\begin{tabular}{|c|c|c|c|c|}
\hline No & Hari/Tgl & Kegiatan & Narasumber & Ket \\
\hline 1 & $\begin{array}{l}\text { Sabtu, } \\
7 \text { Sep } 2018\end{array}$ & Evaluasi sebelum kegiatan penyuluhan & \multicolumn{2}{|c|}{$\begin{array}{l}\text { Tim Penyuluhan dan } \\
\text { Instruktur }\end{array}$} \\
\hline 2 & $\begin{array}{l}\text { Sabtu, } \\
7 \text { Sep } 2018\end{array}$ & $\begin{array}{l}\text { Penyuluhan Hukum Tentang Kekerasan dalam Rumah } \\
\text { Tangga (KDRT) Kepada Anggota Polisi Dan penyidik di } \\
\text { Kepolisian Resort (POLRES) Kabupaten Tanjung } \\
\text { Jabung Barat }\end{array}$ & & \\
\hline \multicolumn{3}{|c|}{ Jam } & & \\
\hline \multicolumn{2}{|c|}{08.30 wib - 09.30 wib } & $\begin{array}{l}\text { Lingkup Kekerasan Dalam Rumah } \\
\text { tangga }\end{array}$ & \multirow{3}{*}{\multicolumn{2}{|c|}{$\begin{array}{l}\text { Tim Penyuluhan dan } \\
\text { Instruktur }\end{array}$}} \\
\hline \multicolumn{2}{|c|}{$09.30 \mathrm{wib}-11.30 \mathrm{wib}$} & Hak-Hak Korban & & \\
\hline \multicolumn{2}{|c|}{$11.00 \mathrm{wib}-12.00 \mathrm{wib}$} & Kewajiban Pemerintah dan & & \\
\hline
\end{tabular}




\begin{tabular}{|c|l|l|l|}
\hline \multicolumn{2}{|l|}{} & Masyarakat & \\
\cline { 1 - 3 } 12.00 wib $-14.00 \mathrm{wib}$ & Isoma & \\
\cline { 1 - 3 } $14.00 \mathrm{wib}-15.30 \mathrm{wib}$ & Pemulihan \& Perlindungan Korban & \\
\hline \multicolumn{2}{|l|}{$15.30 \mathrm{wib}-17.00 \mathrm{wib}$} & Ketentuan Pidana & \multirow{2}{*}{$\begin{array}{l}\text { Tim Penyuluhan dan } \\
\text { Instruktur }\end{array}$} \\
\hline
\end{tabular}

\section{c. Hasil Monitoring dan Evaluasi}

Kegiatan monitoring dan evaluasi dilakukan secara bersamaan selama kegiatan penyuluhan berlangsung. Instrumen yang digunakan meliputi pengamatan secara langsung mengenai sikap dan melalui daftar pertanyaan atau kuis yang diberikan langsung oleh Tim Penyuluhan. Hasil kegiatan monitoring dan evaluasi dapat dilihat pada tabel berikut ini:

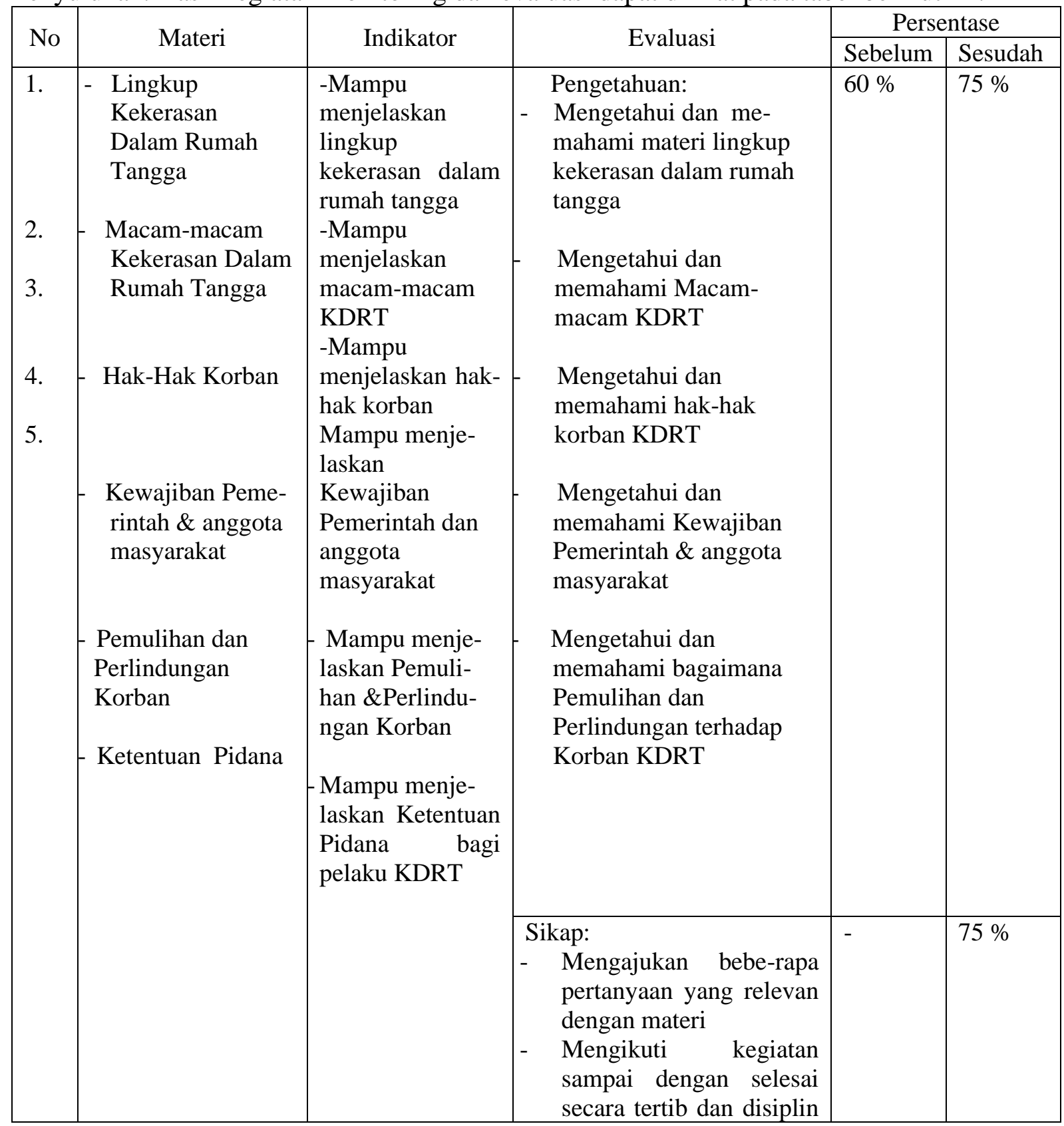




\begin{tabular}{|c|c|c|c|c|c|}
\hline & & & $\begin{array}{l}\text { berpartisipasi secara } \\
\text { aktif. }\end{array}$ & & \\
\hline 2 & $\begin{array}{ll} & \text { Diskusi dan } \\
& \text { Evaluasi }\end{array}$ & $\begin{array}{l}\text {-Mampu } \\
\text { menyampaikan } \\
\text { pemikiran/ide } \\
\text { berkaitan dengan } \\
\text { Penghapusan } \\
\text { Kekerasan Dalam } \\
\text { Rumah Tangga } \\
\end{array}$ & $\begin{array}{l}\text { Peserta mampu } \\
\text { menyampaikan ide } \\
\text { kegiatan Pengahapusan } \\
\text { Kekerasan Dalam } \\
\text { Rumah Tangga }\end{array}$ & $65 \%$ & $80 \%$ \\
\hline
\end{tabular}

Berdasarkan hasil evaluasi yang dilakukan melalui kuis yang dilakukan sebelum maupun setelah kegiatan dilaksanakan serta pengamatan selama kegiatan penyuluhan maka diperoleh hasil sebagai berikut:

1. $75 \%$ peserta penyuluhan mengetahui dan memahami materi tentang KDRT dan mampu menjelaskan isi dari materi berkaitan dengan KDRT.

2. $75 \%$ peserta penyuluhan berpartisipasi secara aktif selama kegiatan berlangsung dengan ditandai pertanyaan-pertanyaan yang diajukan sesuai dengan materi penyuluhan serta menunjukkan kedisiplinan dan tata tertib selama mengikuti kegiatan.

3. $75 \%$ peserta mengetahui bahwa ada kewajiban pemerintah dan anggota masyarakat untuk bertanggung jawab dalam upaya pencegahan kekerasan dalam rumah tangga.

4. $80 \%$ peserta penyuluhan mampu menyampaikan ide pemikiran berkaitan dengan hak-hak korban akibat kekerasan dalam rumah tangga.

Selama kegiatan penyuluhan, peserta menunjukkan sikap antusias dengan ditandai banyaknya pertanyaan yang diajukan oleh para peserta kepada narasumber/instruktur. Beberapa pertanyaan yang diajukan oleh peserta penyuluhan antara lain sebagai berikut:

Pertanyaan:

1. Pertanyaan dari Bapak Rian Ariandi: Perbuatan yang bagaimana yang dapat dikatagorikan Kekerasan Dalam Rumah Tangga?

Jawaban:

Undang-Undang Republik Indonesia Nomor 23 Tahun 2004 tentang Penghapusan Kekerasan Dalam Rumah Tangga Pasal 1 ayat (1) menjelaskan yang dimaksud dengan kekerasan dalam rumah tangga adalah, "setiap perbuatan terhadap seseorang terutama perempuan yang berakibat timbulnya kesengsaraan atau penderitaan secara fisik, sekual, psikologis, dan/atau penelantaran rumah tangga termasuk ancaman untuk melakukan perbuatan, pemaksaan, atau perampasan kemerdekaan secara melawan hukum dalam lingkup rumah tangga".

2. Pertanyaan Bapak Joko Purnomo: Apakah korban kekerasan di dalam rumah tangga itu hanya perempuan? Bagaimana kalau yang melakukan kekerasan adalah perempuan.

Jawaban:

Ruang lingkup rumah tangga dalam Pasal 2 Undang-Undang Nomor. 23 Tahun 2004 tentang PKDRT meliputi:

a. Suami, istri, dan anak. 
b. Orang-orang yang mempunyai hubungan keluarga dengan orang sebagaimana dimaksud pada huruf a karena hubungan darah, perkawinan, persusuan, pengasuhan, dan perwalian, yang menetap dalam rumah tangga tersebut. Orang yang bekerja membantu rumah tangga dan menetap dalam rumah tangga tersebut.

Korban KDRT pada umumnya sebagian besar dialami oleh perempuan (isteri) dan pelakunya adalah suami. Pelaku atau korban KDRT adalah orang yang mempunyai hubungan darah, perkawinan, persusuan, pengasuhan, perwalian dengan suami, dan anakanak bahkan pembantu rumah tangga yang bertempat tinggal dalam satu atap.

Jadi orang-orang yang disebut dalam Pasal 2 ini dapat saja menjadi korban kekerasan, tetapi yang paling rentan menjadi korban kekerasan dalam rumah tangga adalah perempuan dan anak.

3. Pertanyaan Ani Rohim: Apa saja bentuk kekerasan yang dapat digolongkan ke dalam kekerasan dalam rumah tangga, bagaimana kalau suami menyakiti isteri dengan lisannya atau kata-katanya.

Jawaban:

Pasal 5 UUPKDRT, Setiap orang dilarang melakukan kekerasan dalam rumah tangga terhadap orang dalam lingkup rumah tangganya, dengan cara:
a. Kekerasan fisik;
b. Kekerasan psikis;
c. Kekerasan seksual; atau
d. Penelantaran rumah tangga.

4. Pertanyaan Rional: Jika seorang perempuan mengalami kekerasan dalam rumah tangga, apa saja perlindungan yang diberikan?

Jawaban:

Pasal 10 UUPKDRT, korban berhak mendapatkan:

a. Perlindungan dari pihak keluarga, kepolisian, kejaksaan, pengadilan, advokat, lembaga social, atau pihak lainnya baik sementara maupun berdasarkan penetapan perintah perlindungan dari pengadilan;

b. pelayanan kesehatan sesuai dengan kebutuhan medis;

c. penanganan secara khusus berkaitan dengan kerahasiaan korban;

d. pendampingan oleh pekerja social dan bantuan hukum pada setiap tingkat proses pemeriksaan sesuai dengan ketentuan peraturan perundang-undangan; dan

e. pelayanan bimbingan rohani.

5. Pertanyaan Windi: Apa sikap kami jika di sekitar kami tetangga misalnya mengalami kekerasan dalam rumah tangga?

Jawaban:

Meskipun yang mengalami kekerasan dalam rumah tangga adalah tetangga kita, kita dapat melaporkannya kepada Kepolisian terdekat, karena Kekerasan Dalam Rumah Tngga adalah Delik Umum, jadi siapa saja dapat melaporkannya, kecuali yang diatur dalam Pasal 44 ayat 4 UUPKDRT yaitu:

"Dalam hal perbuatan sebagaimana dimaksud pada ayat (1) dilakukan oleh suami tisteri atau sebalaiknya yang tidak menimbulkan penyakit atau halangan untuk menjalankan pekerjaan jabatan atau mata pencaharian atau kegiatan sehari-hari, dipidana dengan pidana penjara paling lama 4 (empat) bulan atau denda paling banyak Rp 5.000.000,- (lima juta rupiah).

\section{PENUTUP}




\subsection{Kesimpulan}

Pengabdian kepada masyarakat dengan melakukan: Penyuluhan Hukum Tentang Kekerasan Dalam Rumah Tangga (KDRT) Kepada Anggota Polisi Dan Penyidik di Kepolisian Resort (POLRES) Kabupaten Tanjung Jabung Barat", menunjukkan bahwa akseptabilitas yakni tingkat penyerapan mitra terhadap kegiatan mengalami peningkatan pengetahuan dan pemahaman mitra tentang materi kegiatan. Yaitu adanya peningkatan pengetahuan dan pemahaman peserta tentang materi Undang-Undang Nomor 23 Tahun 2004 Tahun Tentang Penghapusan Kekerasan Dalam Rumah Tangga, mitra mampu menyampaikan ide atau pemikiran berkaitan dengan KDRT serta dalam penyelesaian KDRT mitra telah menerapkan mediasi penal.

\subsection{Saran}

Kegiatan penyuluhan sangat bermanfaat bagi masyarakat, khususnya Aparat Penegak Hukum (Kepolisian) dalam penanggulangan KDRT, karena penegakan hukum tidak harus diselesaikan dengan penegakan hukum pidana, contohnya dalam KDRT dapat dilakukan mediasi penal.

\section{DAFTAR PUSTAKA}

\section{Buku- Buku}

Departemen Pendidikan dan Kebudayaan, Kamus Besar Bahasa Indonesia. Balai Pustaka. Jakarta. 1993.

Luhulima, Achie Sudiarti, Pemahaman Bentuk-Bentuk Tindak Kekerasan Terhadap Perempuan dan Alternatif Pemecahannya. PT. Alumni, Jakarta.2000.

Prayudi, Guse, Berbagai Aspek Tindak Pidana Kekerasan Dalam Rumah Tangga, Merkid Press. Jogjakarta.2008.

Soeroso, Moerti Hadiati. Kekerasan Dalam Rumah Tangga dalam Perspsektif Yuridis Fiktimologi, Sinar Grafika, Jakarta, 2010.

Saraswati, Rika, Perempuan dan Penyelesaian Kekerasan Dalam Rumah Tangga, Citra Aditya Bakti, Bandung. 2009.

Jurnal Perempuan 22, Memikirkan Perkawinan, Yayasan Jurnal Perempuan, Jakarta 2002.

\section{Peraturan Perundang-Undangan.}

R. Soesilo, KUHP serta Komentar lengkap Pasal demi Pasal, Politea, Bogor, 1993. 
, Undang-Undang Tentang Perkawinan. UU Nomor 1 Tahun 1974.

LNRI Tahun 1974 Nomor 1 TLN RI Nomor 3017.

, Undang-Undang Tentang Pengesahan Konvensi Mengenai Penghapusan Segala Bentuk Diskriminasi Terhadap Wanita, UU No 7 Tahun 1984 LNRI Tahun 1984 Nomor 29, TLN RI Nomor 3277.

Undang-Undang Tentang Penghapusan Kekerasan Dalam Rumah Tangga, UU Nomor 23 Tahun 2004, LNRI tahun 2004 Nomor 95, TLN RI Nomor 4419. 